\title{
PREVALENCE OF HEPATITIS B VIRUS AND ASSOCIATED RISK FACTORS IN IRULA TRIBAL POPULATION
}

\section{RAMYA DINESH E, RAMALAKSHMI S*}

\author{
Department of Microbiology, Karpagam University, Karpagam Academy of Higher Education, Coimbatore - 641 021, Tamil Nadu, India. \\ Email: arulaksh24@gmail.com
}

Received: 18 March 2017, Revised and: 24 April 2017

\section{ABSTRACT}

Objective: The study is to analyze the prevalence of infections caused by hepatitis B virus (HBV), and to analyze of risk factors for hepatitis B surface antigen (HBsAg) transmission among the Irula tribes of Tamil Nadu.

Methods: Serum samples were collected from 350 participants of Irula tribes from 15 different locations of Tamil Nadu. All serum samples were tested for serological markers of HBV (HBsAg) by $3^{\text {rd }}$ generation enzyme-linked immunosorbent assay kit, and the data were subjected to analyze using SPSS (version 17.0) and Chi-square test to determine the risk factors of HBV among Irula tribes.

Results: In the study, HBsAg positivity was observed in a higher percentage in males $10(8.47 \%)$ than females 9 (3.54\%) and their all age groups indicate the high prevalence of HBV infection in Irula tribes. Analysis of risk factors showed that jaundice in family (JF), tattooing, series of injection, sexual promiscuity, and surgery with blood transfusion plays a major role in transmission in spread of HBV.

Conclusion: Hepatitis B is a major health problem in Irula tribes and needs to design intervention strategies among Irula tribal population.

Keywords: Hepatitis B virus, Hepatitis B infection, Risk factors, Irula tribes.

(C) 2017 The Authors. Published by Innovare Academic Sciences Pvt Ltd. This is an open access article under the CC BY license (http://creativecommons. org/licenses/by/4. 0/) DOI: http://dx.doi.org/10.22159/ajpcr.2017.v10i8.18552

\section{INTRODUCTION}

Hepatitis B virus (HBV) was discovered by Blumberg and HBV is an Hepadnavirus (Hepa from hepatotropic and DNA is its genetic material, i.e., hepatitis B is DNA virus) and it has circular genome partially composed of double-stranded DNA [1]. Hepatitis B is "serum hepatitis," and the infection is a major cause of morbidity and mortality in the continent of Asia and Africa [2].

Hepatitis B is most serious type of viral hepatitis and one of the major problems of global public health. According to the WHO, 4-6 crores people in India are carriers, and $2-5 \%$ of India population may be affected by the HBV. It is estimated that every year 1 lakh people die due to the viral hepatitis including hepatitis B and C in India [3].

India has the second largest concentrations of tribal in the world. The tribal population of the country as per the 2001 census is 84.3 million, constituting $8.2 \%$ of the total population with $91.7 \%$ of them living in rural areas and $8.3 \%$ in urban areas [4]. Although scheduled tribes are accorded with special status under the fifth/sixth schedules of the Indian Constitution, their status on the whole, especially health remains unsatisfactory [5]

Indian tribal communities are experiencing a latent phase that is potentially a precursor for infectious diseases like hepatitis. Tribal identity differs from caste identity in terms of language, social organization, religious affiliation, economic patterns, geographic location, and self-identification [6].

In India, the commonly accepted term for tribal people is Adivasi, which refers to people living as a strongly knit community they are originally lived in forests or in rural areas [7]. They take vegetables and meat food including rats, snakes but they do not eat beef. These tribes used to make living by catching rats and snakes. Many Irulas are forced out of forest conservation reserves with the introduction of strict Forest
Acts in 1976. These Irulas started moving to neighboring villages in search of new livelihood. Tattooing is still frequently seen especially on the forehead. Their lifestyle makes them vulnerable to a variety of infectious diseases $[8,9]$.

Hepatitis B infection is always reported to be associated with risk factors such as tattooing, alcoholism, surgery, injections, blood transfusion, jaundice, and sexual promiscuity (SP) $[6,10]$. Since there is a need to study the prevalence of HBV with associated risk factors in the tribal population of India especially in Tamil Nadu. This study was conducted on specific South Indian Irula tribes in Tamil Nadu.

\section{METHODS}

Study area

A total of 15 habitats of Irula, two from Kanchipuram (district), five from Cuddalore (district), and eight from Thiruvallur (district) of Tamil Nadu in India were randomly selected for the study.

\section{Collection of demographic data}

The Irula tribal communities were persuaded by the tribal leaders to converge at the nearest primary health centers for sample collection. The details and purpose of the study were thoroughly explained to all the individuals. The written consent was obtained from the participants in their vernacular language. Demographic details such as age, sex, educational level, alcoholism, tattooing, history of jaundice $(\mathrm{HJ})$, and hospitalization were collected using the questionnaire pro forma formatted and approved by the ethical committee for this study.

\section{Sample collection}

About $5 \mathrm{ml}$ of venous blood was collected and transported in dry ice. The collected blood samples were centrifuged to separate the serum with proper labeling. The serum samples were stored immediately at $-20^{\circ} \mathrm{C}$. 
Study population

The study population consisted of 372 participants of Irulas, and the inclusion criteria were above 18 years of age.

\section{Serology}

The serum samples were screened for the markers of HBV using the commercial enzyme-linked immunosorbent assay test kits. Hepatitis B surface antigen (HBsAg) was detected by Hepanosticka II (Organon Teknika, Belgium). Then, all the positive cases were retested thrice for the confirmation of HBsAg.

\section{Statistical analysis}

Statistical package for social software SPSS (version 17.0) was used for analyzing the data. The Chi-square test was used to find out the significance of HBV with risk factors. The $p<0.05$ was used to indicate statistical significance.

\section{RESULTS}

Out of the 372 serum samples collected, 118 and 254 samples were men and women, respectively (Table 1 ). HBsAg positivity reaction was detected in 19 (5.10\%) out of 372 participants. In the study, HBsAg positivity was observed in a higher percentage in the males $10(8.47 \%)$ than females 9 (3.54) and their all age group indicates the high prevalence of HBV infection in Irula tribes.

High infectivity of HBV can be correlated for both men and women in age group of 31-40, and no infectivity has been reported for age group of 71-80 for men and women. The entire study subjects (372) among the tribal population were analyzed for 10 different risks and behavioral factors and correlated with HBsAg as evidence for HBV chronic infection, and the analysis was statistically analyzed. It is seen that HJ, alcoholism, tattooing, surgery with or without blood transfusion and intravenous drug use (IDU), and migration were statistically significant at risk factors for chronic HBV infection (HBsAg positive) among Irula tribes (Table 2).

Out of all the risk factors, alcoholism shows high infectivity of HBV and the series of injection (SI) as risk factor showed the least infectivity.

In the tribal community setting, the common observation made was that there were combinations of risk factors in 372 (100\%) study subjects analyzed. The details of these combined risk factors patterns are provided in Table 3. The analysis of frequency in a combination of risk factors among Irula tribes (Table 3 ) and occurrence of HBV positivity is shown the following: The predominant risk factors combination among the study population were $\mathrm{HJ}+\mathrm{JF}+\mathrm{A}+\mathrm{T}+\mathrm{SBT}+\mathrm{M}, \mathrm{HJ}+\mathrm{JF}+\mathrm{A}+\mathrm{M}$, $\mathrm{T}+\mathrm{SI}+\mathrm{M}$, and $\mathrm{JF}+\mathrm{T}+\mathrm{SP}$. When HBsAg positivity was analyzed with risk factor pattern, higher $\mathrm{HBsAg}$ positivity was seen in $\mathrm{HJ}+\mathrm{JF}+\mathrm{A}+\mathrm{T}+\mathrm{SBT}+\mathrm{M}$, $\mathrm{HJ}+\mathrm{JF}+\mathrm{A}+\mathrm{M}, \mathrm{HJ}+\mathrm{T}+\mathrm{S}+\mathrm{SP}+\mathrm{M}, \mathrm{JF}+\mathrm{T}+\mathrm{S}$, and $\mathrm{JF}+\mathrm{T}$ combinations

\section{DISCUSSION}

The HBsAg prevalence ranged from 1.86\% in Kolli Hill tribes of Tamil Nadu [6], none of them $(0.00 \%)$ were positive for HBsAg in Nilgiri Tribes of Tamil Nadu [11], 3\% of HBsAg positivity was found in Indian gypsies of Tamil Nadu [12], Kurumba, Toda, Kotta, and Irula tribes were analyzed for the HBV in Nilgiri, Tamil Nadu on 2001 [13], and $0.8 \%$, 0.9\%, 0.9\%, 3.7\%, and 1.7\% Lodha, Saora, Khadia, Mankidia, and Juang tribes of Odisha [14].

This study shows that HBV among the Irula tribes of Tamil Nadu reached $5.10 \%$ and males $10(8.47 \%$ ) and females 9 (3.54) were positive for HBsAg and their all age group indicate the high prevalence of HBV infection in Irula tribes (Table 1). The results show that there is a high prevalence of hepatitis B infection in Irula tribes when compared to the other tribes of Tamil Nadu, India $[6,11,12]$. Likewise, $11.11 \%$ of HBsAg positivity was found in Irula tribes by Ashok et al. [8]. These study reports of HBV infection indicates that high levels of transmission may occur within the Irula tribes and HBV prevalence rate in earlier study among Irula tribes was low.
Table 1: Age and sex distribution data from Irula tribal community for HBV infectivity

\begin{tabular}{llllll}
\hline $\begin{array}{l}\text { Age } \\
\text { group }\end{array}$ & Male & & & Female & \\
\cline { 2 - 3 } \cline { 5 - 5 } & $\begin{array}{l}\text { Number of } \\
\text { tested }\end{array}$ & HBsAg+ve & & $\begin{array}{l}\text { Number of } \\
\text { tested }\end{array}$ & HBsAg+ve \\
\cline { 1 - 1 } $18-20$ & 16 & 0 & 25 & 1 \\
$21-30$ & 34 & 2 & 81 & 2 \\
$31-40$ & 18 & 4 & 75 & 3 \\
$41-50$ & 22 & 2 & 42 & 2 \\
$51-60$ & 17 & 1 & 25 & 1 \\
$61-70$ & 8 & 1 & 6 & 0 \\
$71-80$ & 3 & 0 & 0 & 0 \\
Total $(\%)$ & $118(31.72)$ & $10(8.47)$ & $254(68.27)$ & $9(3.54)$ \\
\hline
\end{tabular}

HBV: Hepatitis B virus

Table 2: Pattern of risk factors associated with the Irula tribal population and their positivity for $\mathrm{HBV}$

\begin{tabular}{llll}
\hline S.No. & $\begin{array}{l}\text { Risk factors (study } \\
\text { subject } \mathbf{n = 3 7 2 )}\end{array}$ & $\begin{array}{l}\text { HBsAg+ve } \\
\text { cases (\%) }\end{array}$ & p value \\
\hline 1 & HJ (n=199) & $14(7.03)$ & 0.01 \\
2 & JF (n=258) & $14(5.42)$ & 0.18 \\
3 & Alcoholism (n=191) & $15(7.85)$ & 0.00 \\
4 & Tattooing (n=236) & $10(4.23)$ & 0.97 \\
5 & SBT (n=39) & $4(10.25)$ & 0.06 \\
6 & S (n=54) & $7(12.96)$ & 0.00 \\
7 & IDU (n=39) & $3(10.25)$ & 0.01 \\
8 & SI (n=79) & $2(2.53)$ & 0.43 \\
9 & SP (n=108) & $6(5.55)$ & 0.45 \\
10 & Migration (n=153) & $11(7.18)$ & 0.71 \\
\hline
\end{tabular}

HBV: Hepatitis B virus, HBsAg: Hepatitis B surface antigen, A: Alcoholism, HJ: History of jaundice, IDU: Intravenous drug use, JF: Jaundice in family, SI: Series of injection, SP: Sexual promiscuity, S: Surgery without blood transfusion, SBT: Surgery with blood transfusion, T: Tattooing, M: Migration

Table 3: Frequency of combination of risk factors in HBV positivity among Irula tribes

\begin{tabular}{|c|c|c|c|}
\hline Groups & $\begin{array}{l}\text { Risk factor } \\
\text { combinations }\end{array}$ & $\begin{array}{l}\text { Total number of } \\
\text { study subjects } \\
n=100(\%)\end{array}$ & $\begin{array}{l}\text { HBsAg+ve } \\
n=22(\%)\end{array}$ \\
\hline 1 & $\mathrm{HJ}+\mathrm{JF}+\mathrm{A}+\mathrm{T}+\mathrm{SBT}+\mathrm{S}+\mathrm{M}$ & $3(0.80)$ & - \\
\hline 2 & $\mathrm{HJ}+\mathrm{JF}+\mathrm{A}+\mathrm{T}+\mathrm{SBT}+\mathrm{M}$ & $32(8.60)$ & $3(9.37)$ \\
\hline 3 & $\mathrm{HJ}+\mathrm{JF}+\mathrm{A}+\mathrm{T}+\mathrm{M}$ & $22(5.91)$ & $1(4.54)$ \\
\hline 4 & $\mathrm{HJ}+\mathrm{JF}+\mathrm{A}+\mathrm{M}$ & $80(21.50)$ & $6(7.50)$ \\
\hline 5 & $\mathrm{HJ}+\mathrm{JF}+\mathrm{M}$ & $21(5.64)$ & $1(4.76)$ \\
\hline 6 & $\mathrm{JF}+\mathrm{T}+\mathrm{S}$ & $12(3.22)$ & $1(8.33)$ \\
\hline 7 & $\mathrm{~A}+\mathrm{IDU}+\mathrm{SP}+\mathrm{M}$ & $16(4.30)$ & $2(12.5)$ \\
\hline 8 & $\mathrm{JF}+\mathrm{T}$ & $12(3.22)$ & $1(8.33)$ \\
\hline 9 & $\mathrm{~T}+\mathrm{S}+\mathrm{SI}$ & $24(6.45)$ & $1(4.16)$ \\
\hline 10 & $\mathrm{~A}+\mathrm{IDU}+\mathrm{SP}$ & $11(2.95)$ & - \\
\hline 11 & $\mathrm{HJ}+\mathrm{T}+\mathrm{S}+\mathrm{SP}+\mathrm{M}$ & $2(0.53)$ & $2(100)$ \\
\hline 12 & $\mathrm{HJ}+\mathrm{A}+\mathrm{IDU}+\mathrm{SI}+\mathrm{M}$ & $2(0.53)$ & - \\
\hline 13 & $A+I D U+S P$ & $1(0.26)$ & - \\
\hline 14 & $\mathrm{~T}+\mathrm{SI}$ & $48(12.90)$ & $1(2.08)$ \\
\hline 15 & $A+I D U$ & $6(1.61)$ & - \\
\hline 16 & $\mathrm{HJ}$ & $11(2.95)$ & - \\
\hline 17 & $\mathrm{JF}+\mathrm{T}+\mathrm{SP}$ & $25(6.72)$ & - \\
\hline 18 & S & $14(3.76)$ & \\
\hline 19 & $\mathrm{HJ}+\mathrm{T}$ & $9(2.41)$ & - \\
\hline 20 & $\mathrm{SBT}+\mathrm{SI}+\mathrm{SP}$ & $4(1.07)$ & - \\
\hline 21 & $\mathrm{~A}+\mathrm{T}+\mathrm{S}+\mathrm{SI}+\mathrm{SP}+\mathrm{IDU}$ & $1(0.26)$ & - \\
\hline 22 & No risk factor & $16(4.30)$ & - \\
\hline
\end{tabular}

A: Alcoholism, HJ: History of jaundice, IDU: Intravenous drug use, JF: Jaundice in family, SI: Series of injection, SP: Sexual promiscuity, S: Surgery without blood transfusion, SBT: Surgery with blood transfusion, T: Tattooing, M: Migration

The factors associated with HBV infection are identified in this study with 10 different risk factors with behavioral aspects. The very few 
studies in India have been studied with the risk factors in Irula tribes. The risk factors selected for the prevalence of HBsAg by Kurien et al. and Kalaivani et al. $[6,10]$. This study demonstrates that there is a strong association with gender, migration (place of living comes under this category), HJ, alcoholism, tattooing, surgery with or without blood transfusion, and IDU were statistically significant at risk factors for chronic HBV infection (HBsAg positive) among Irula tribes (Table 2).

Among the Irula tribes, $\mathrm{HJ}+\mathrm{JF}+\mathrm{A}+\mathrm{T}+\mathrm{SBT}+\mathrm{M}, \mathrm{HJ}+\mathrm{JF}+\mathrm{A}+\mathrm{M}, \mathrm{T}+\mathrm{SI}+\mathrm{M}$, and $\mathrm{JF}+\mathrm{T}+\mathrm{SP}$ combinations were found as highly associated risk pattern for $\mathrm{HBV}$ infection. Higher HBsAg positivity was seen in $\mathrm{HJ}+\mathrm{JF}+\mathrm{A}+\mathrm{T}+\mathrm{SBT}+\mathrm{M}$, $\mathrm{HJ}+\mathrm{JF}+\mathrm{A}+\mathrm{M}, \mathrm{HJ}+\mathrm{T}+\mathrm{S}+\mathrm{SP}+\mathrm{M}, \mathrm{JF}+\mathrm{T}+\mathrm{S}$, and $\mathrm{JF}+\mathrm{T}$ combinations (Table 3 )

This study revealed that the JF, tattooing, surgery with blood transfusion, SI, SP, and migration were statistically significant $(\mathrm{p}<0.05)$ and these factors were notable risk factors for HBV among tribal population.

The possible routes of transmission of HBV infection among the tribes were perinatal transmission $[15,16]$, accidental inoculation of contaminated blood during the certain cultural practices such as tattooing and others $[5,15,17,18]$. The relation between tattooing, surgery with blood transfusion, and SI with the transmission of certain infectious diseases is transmitted by blood and blood products $[6,19]$. Basically hepatitis B is a blood-borne disease, based on this tattooing, surgery with blood transfusion, and SI may play a key role in transmission of hepatitis B infection.

Alcohol-related liver disease is a significant burden on health, with alcohol consumption accounting for $3.8 \%$ of global mortality. Alcohol is a major cause of liver cirrhosis in the Western world. It shows that more exposure to poor sanitation and use of more alcohol are the chances of spread of more HBV in tribal people [20].

The distribution of HBV was observed in both male and female in between age group of 24 and 47 years. High HBV prevalence in both sex was reported from rural areas of Andhra Pradesh [21].

Hepatitis B infection is transmitted through close personal contact or blood or body fluids contamination as skin infections and polygamy or multiple sexual partners $[15,16]$. A study was conducted among the tribal area of Jawadhu Hills regarding the awareness of family planning. With a total of 200 women aged between 15 and 45 years revealed that almost $94 \%$ population had inadequate knowledge on family planning. The study also revealed that there is no correlation between the risk factors such as age, religion, etc., and family welfare [22]. Likewise, JF and SP have a higher significant in the Irula tribes. The Irula tribes used to make a living by catching rats and snakes. Their lifestyle makes them vulnerable to a variety of infectious diseases [23]. So migration, i.e., place of living can also be one of the main reasons of HBV transmission in Irula tribes.

\section{CONCLUSION}

This study shows high rates of HBsAg among Irula tribes than other tribes of Tamil Nadu in India. Horizontal transmission is related to poor sanitation, tattooing, sexual behavior, surgery with blood transfusion, and migration in the Irula tribes. Further studies can be conducted to assess vertical transmission of HBV in the Irula tribes.

\section{ACKNOWLEDGMENT}

The authors are thankful to the Vice Chancellor, the Dean of Karpagam University, Coimbatore. Hearty thankful to (late) Dr. P. Rajendran, Professor of Microbiology, Madha Medical College, Chennai, for valuable guidance, encouragement and support to continue our research work.

\section{REFERENCES}

1. Blumberg BS. Australia antigen and the biology of hepatitis B. Science 1977;197(4298):17-25

2. Nworie O, Jerry OO, Ekuma UO, Ukpabi NN, Onu EN. Studies on the seroprevalence of hepatitis B virus infection among school children in Ohaukwu, Ebonyi state, Nigeria. World Appl Sci J 2015;33(11):1767-72.

3. World Health Organization. World Health Statistics. Geneva: World Health Organization; 2015.

4. Census Organisation. Registrar General of India. India: Census Organisation; 2001.

5. Geethavani B, Sangamithra V, Balamuruganvelu S, Rajendran P. Seroprevalence of syphilis and leptospirosis among tribal population of Tamil Nadu and qualitative analysis of the risk factors associated with the diseases. Int J Pharm 2014;4(4):190-4.

6. Kalaivani V, Rajendran P, Thyagarajan SP, Rajesh PK, Hari R, Selvakumar C, et al. The seroprevalence of hepatitis B and C viruses and the associated risk factors in the Kolli hills tribal population of Tamil Nadu. Biomedicine 2001;21(1):7-13

7. Government of India. The Constitution of India. New Delhi: Government of India; 1949.

8. Gnanasekaran A, Paramasivam R, Mohan K, Daniel JC, Murugasan K, Perumal Kannabiran U, et al. Seroprevalence of certain bacterial and viral infections among the Irula tribal population of Marakkanam, Tamil Nadu state, India. Prim Health Care Res Dev 2013;14(2):185-91.

9. Sharma AV. Adivasis of Kodiakkarai. Chennai: Publications of the Government Museum; 1962.

10. Kurien T, Thyagarajan SP, Jayaseelan L, Peedicayil P, Sivaraman S, Hansdak SG, et al. Community prevalence of hepatitis B infection and modes of transmission in Tamil Nadu, India. Indian J Med Res 2005;121:670-5.

11. Krishnasamy N, Senthilkumar R, Sathishkumar E, Lakshmi J, Ramachandar S, Rameshkumar M. Prevalence of hepatitis B and C viral markers among the tribal population of Nilgiris, Tamil Nadu. Int J Med Res Health Sci 2015;4(3):889.

12. Murugan T, Rajendran P. A study on viral (HIV \& HBV) and bacterial (syphilis) secually transmitted diseases (STD) among Indian gypsies population of Kanchipuram district of Tamil Nadu, India. Indian J Appl Microbiol 2011;1(2):64-7.

13. Rajendran P, Hussain IA, Thyagarajan SP. HBs Ag and HIV in Nilgiri tribal population of Tamil Nadu. Indian J Appl Microbiol 2001;1:37-9.

14. Dwibedi B, Sabat J, Ho LM, Singh SP, Sahu P, Arora R, et al. Molecular epidemiology of hepatitis B virus in primitive tribes of Odisha, eastern India. Pathog Glob Health 2014;108(8):362-8.

15. Joshi SH, Gorakshakar AC, Mukherjee M, Rao VR, Sathe MS, Anabhavane SM, et al. Prevalence of HBsAg carriers among some tribes of Madhya Pradesh. Indian J Med Res 1990;91:340-3.

16. Murhekar MV, Murhekar KM, Arankalle VA, Sehgal SC. Epidemiology of hepatitis B infection among the Nicobarese - A mongoloid tribe of the Andaman and Nicobar Islands, India. Epidemiol Infect 2002;128(3):465-71.

17. Nishioka SA, Gyorkos TW. Tattoos as risk factors for transmissiontransmitted diseases. Int J Infect Dis 2001;5:27-34.

18. Chandra M, Khaja MN, Farees N, Poduri CD, Hussain MM, Aejaz Habeeb M, et al. Prevalence, risk factors and genotype distribution of $\mathrm{HCV}$ and $\mathrm{HBV}$ infection in the tribal population: A community based study in south India. Trop Gastroenterol 2003;24(4):193-5.

19. Long GE, Rickman LS. Infectious complications of tattoos. Clin Infect Dis 1994;18:610-9.

20. Alotaibi A, Khan J. Study of hepatitis B infection and its genotypes in tribal people. Asian J Pharm Clin Res 2017;10(4):51-5.

21. Kumar MR, Rao MS, Pulicherla KK, Ghosh M, Kumar MH, Rekha VP, et al. Studies on the distribution of hepatitis B (HBV) and human immunodeficiency virus (HIV) - Their relation to blood groups and rhesus (RH) factor in Guntur district of Andhra Pradesh, India. Asian J Pharm Clin Res 2012;16(1):109-11.

22. Missiriya S, Priya M, Pavithra G, Pavithran G, Priyanka K, Sandhiya R. Assess the knowledge and practice of reproductive aged tribal women on family welfare methods. Int J Pharm Pharm Sci 2017;9(1):121-4.

23. Ramasamy S, Balakrishnan K, Pitchappan RM. Prevalence of sickle cells in Irula, Kurumba, Paniya and Mullukurumba tribes of Nilgiris (Tamil Nadu, India). Indian J Med Res 1994;100:242-5. 